\title{
SETTING THE GUIDELINES FOR TEACHING MARITIME ENGLISH ON THE BASIS OF LANGUAGE SKILLS AND THE EVALUATION OF THE VOCABULARY THEMES IMPORTANCE IN THE CONTEXT OF SEAGOING PRACTICE. A CASE STUDY
}

\author{
Vilma Pranckevičiūtè \\ Lithuanian Maritime Academy
}

\begin{abstract}
The article analyzes the requirements set out in legal documents for Maritime English (ME) teaching and the results of the survey on the view of students', who completed seagoing training, needs for $M E$, in order to set the guidelines for further development of the ME teaching. The survey showed that understanding technical texts and listening were given the greatest importance. In addition, radio communication proved to be one of the most needed skills. As regards the evaluation of the topicality of the ME vocabulary for the work at sea, the students of Marine Engineering and Marine Navigation evaluated some topics of other programme as important ones. Thus, one of the areas to take into account is a wider view on the professional ME topics that are included in the courses for both marine engineers and navigators. Other suggestions for further development of the ME teaching are to pay more attention to radio communication and to develop the skills of reading technical documentation.
\end{abstract}

Keywords: Maritime English, syllabus, language skills.

\section{Introduction}

Maritime English (ME) is still a lingua franca in the maritime shipping. ME is a significant part of maritime training and is regulated by the Convention on Standards of Training, Certification and Watchkeeping (STCW) 2010, as amended, Safety of Life at Sea (SOLAS) Convention. Recommendations for the implementation of formal requirements are provided in the Model Course 3.17 Maritime English (2015). ME is also a form of English for Specific Purposes (ESP), which is taught to professionals in their fields of study or work in order to facilitate and enhance their functioning at their work places. In the case of ME, it is also a must for seafarers to be able to communicate in English, as it is indicated in the documents mentioned above. Therefore, it is essential to meet the needs of seafarers and comply with the requirements of the international legal documents while teaching $\mathrm{ME}$ to the 
students of maritime professions. All these requirements must be incorporated in the syllabuses for ME teaching of maritime training institutions.

The aim of the article is to set guidelines for further development of ME institutional teaching taking into account the formal requirements for $\mathrm{ME}$ in the maritime area as well as topical needs of seafarers working at sea and reformulating both syllabus structure and content in order to meet the needs of ME students and legal requirements.

With this in mind, the following objectives were set: to review the formal requirements for ME teaching in terms of vocabulary and language skills; to analyze the experienced students' needs for different ME vocabulary themes and language skills; to suggest areas for further development of ME teaching in terms of motivation for language skills development and thematic syllabus topics.

Methodology and methods of the research. The study includes the analysis of scientific literature and survey results. The structured survey in writing was conducted in order to distinguish students' preferences for different language skills and ME vocabulary areas. A total number of questionnaires delivered was 60;56 students filled the questionnaires. Only the students having the seagoing practice experience were questionned so that they could refer to actual and topical needs for $\mathrm{ME}$ at sea. The students were also given an open question on the ME teaching and the content analysis of their answers was carried out. All the respondents studied ME on the basis of unamended syllabus based on 2009 edition of the Model Course 3.17 Maritime English (Model Course (MC)).

The limitations of the study include quite a small number of seafaring students questioned. The study is noted as a case study of the Lithuanian Maritime Academy (LMA). In order to make more generalized conclusions on the issue, more students and institutions could be involved in the research. The study can serve as a pilot study for further investigation. Another limitation is that the ME programme for marine electro-technical engineers (ETOs) is not included in the study.

\section{Legal Requirements for ME and Language Skills}

The requirements set out in the STCW 2010 emphasize the importance of a seafarer to be able to communicate (Table AII/1: "Use the Inernational Maritime Organisation (IMO) Standard Marine Communication Phrases (SMCP) and use English in written and oral form"). Also, as Trekner and Cole (2000) point out "the communication skill of writing is given much higher priority than previously by comparing the requirements set in STCW 78 and the 2010 Manilla amendments". In addition, the imperative to enhance students' communicative abilities is repeatedly introduced in the Model Course 3.17 by selecting "the Communicative Approach as the principal means of instruction and student learning" (MC, p. 109).

The Model Course 3.17 is divided into General Maritime English (GME) designed to teach general English (phonology, grammar, structures, etc.) in the 
maritime context and Specialised Maritime English (SME). The entry level for GME is elementary language level that corresponds to A1-A2 level according to the Common European Framework of Reference for Languages (CEFR) (MC, p. 25). A formal requirement for all secondary school graduates is to achieve the English language proficiency of B2 level; however, practice shows that it is not always the case. Despite some students' proficiency of C1-C2 and general opinion that most of them reach the declared B2 level, quite a few finish secondary schools with lower level of English. As Ilgūnaitienè et al. (2015) point out, the results of undergraduates' diagnostic English tests showed CEFR levels of A2 (51\%), B1 $(26 \%)$ and B2 (23\%). So, the students admitted to LMA have already achieved A2 or B1 level at secondary schools and do not require so much language support. However, the specific vocabulary included in GME is not included in SME, and a course covering basic thematic vocabulary is offered at the beginning of the studies (Introduction to Maritime English).

SME is designed for developing specific skills related to different professional areas: Officer in Charge of Navigational Watch (Marine Navigator) and Officer in Charge of Engineering Watch (Marine Engineer). The implementation of the above at LMA is ensured through the ME courses. The 2015 edition of the Model Course introduces the requirements for marine electro-technical officers, but that part of Manilla Amendments is not covered in this study.

The Model Course offers both syllabus content and structure for teaching ME. A syllabus is (a plan showing) the subjects or books to be studied in a particular course, especially a course that leads to an exam. [2] The types of the syllabus can be product-oriented (structural, situational, notional/functional) or process-oriented (task-based, learner-led, proportional). [1]

According to the Model Course, a syllabus shall include all of these types as [1] suggests that each syllabus contains features of all types with the leading type. The ME syllabus is thematic, based on vocabulary topics learnt with additional grammar and other language support due to students' quite good knowledge of general English. Also, it is product-oriented as students are supposed to show a certain level of language knowledge at the end of their ME studies by passing the final examination.

The Model Course distinguishes English language competencies or language systems (grammar, vocabulary and pronounciation, the latter being a part of vocabulary) and four language skills divided into receptive (listening, reading) and productive (writing, speaking) ones (MC, p. 128-176). The MC suggests developing receptive skills first with furher emphasis on the productive ones. 


\section{ESP and Needs Analysis}

As it is widely agreed, ME is a part of ESP where the needs of students' professional activity for English cannot be omitted in the development of a study programme. The Model Course also suggests the idea that "the instructor should select and adapt the topics to suit the needs of the trainees" (p. 75). In addition, the instructors' manual advises to draw an individual learning plan (ILP) for each student placing the responsibility of its development on the student himself/herself (MC, p. 113). It might be very appealing but not always possible to form such plans having larger groups of students. In addition, this burden of responsibility might seem inappropriate if a student does not have a clear understanding what life at sea is like, what he/she will actually require on board and if it is reasonable to offer students the content of the ME course which is quite relevant to the practical work at sea. The intention of this study is to attempt finding common denominators between the topics recommended by the Model Course and the ME needs of students having experience of seagoing practice.

\section{Survey Results and Discussion}

The questionnaire, according to which the survey was conducted, comprised questions on the importance of language skills used for professional activities as well as different topics of ME vocabulary to be evaluated according to their importance for the work at sea.

The first question was on language skills used on board and their relative importance while working at sea.

\section{Language Skills}

CEFR distinguishes four language skills with the emphasis on speaking skills by distinguishing them into spoken interaction and spoken production. [1] This way, speaking seems to be given more emphasis than other skills. However, the most usual approach to developing language skills is to develop all four language skills as it is given in the Model Course: "This model course gives practice in all four skills to fulfil the competences regarding English language proficiency in the STCW Code" (MC, p. 150). Frequently, at least two skills are used for communication, e.g. in dialogues, active listening skills are necessary; in writing, the ability to read a written text and correct mistakes is important. Therefore, to keep the balance, the productive language skills (speaking and writing) were divided into the interactive or monologue communication skills, while the receptive ones (reading and listening) were separated into receiving general idea or specific information. 


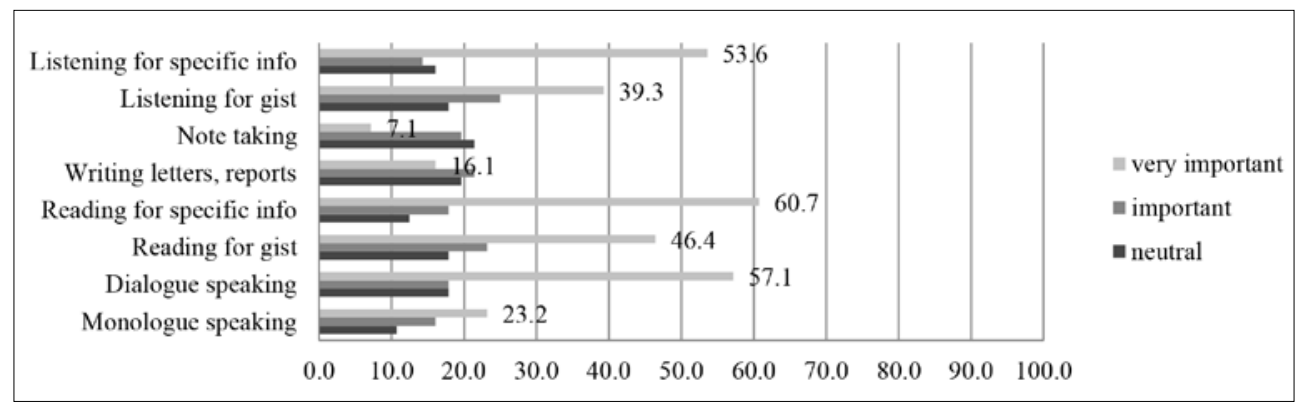

Figure 1. General overview of the importance of language skills for work at sea.

According to Figure 1, students focus on three areas of language skills: reading and listening for specific inormation and dialogue speaking. It is interesting to note that they do not regard writing as an important skill. This might be due to the specificity of their seagoing practice, as they act on board in the position of the lowest rank of a cadet with the lowest responsibilities requiring no writing skills. Taking into account all the documentation to be filled and written by the officers on board, writing is an important skill, therefore, this fact should be an indicator for lecturers to provide additional motivation for writing activities as students do not seem motivated enough by their present experience at sea.

The difference between marine navigators and marine engineers' language skills is also notable (see Figures 2 and 3). Marine navigators have more diverse interest in learning different language skills. Despite this, their self-evaluation of the writing skills is low. The results of the survey show that marine engineers are more aim-oriented and eager to practice just some skills that seem useful for them. Possibly, lecturers need to put additional efforts to show them the importance of other skills they require but are not interested in. Yet.

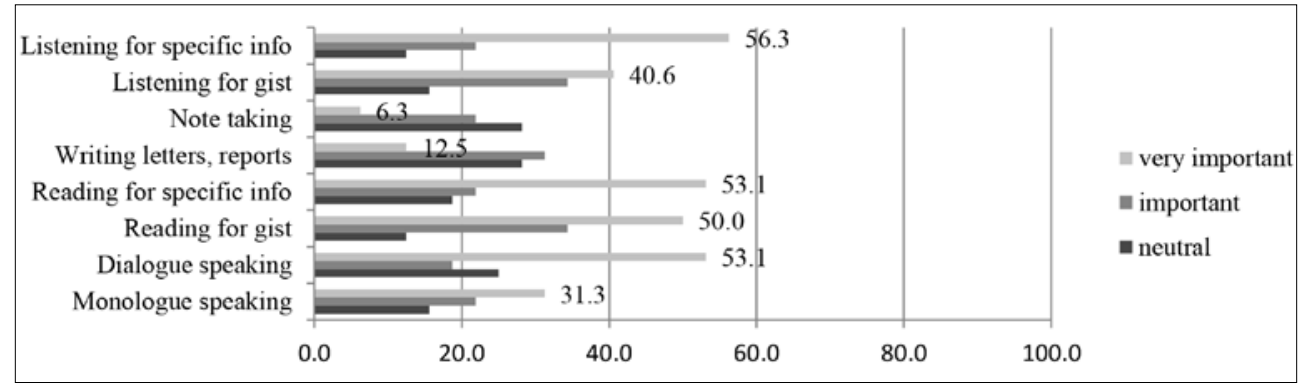

Figure 2. The importance of language skills for work at sea, marine navigation students. 


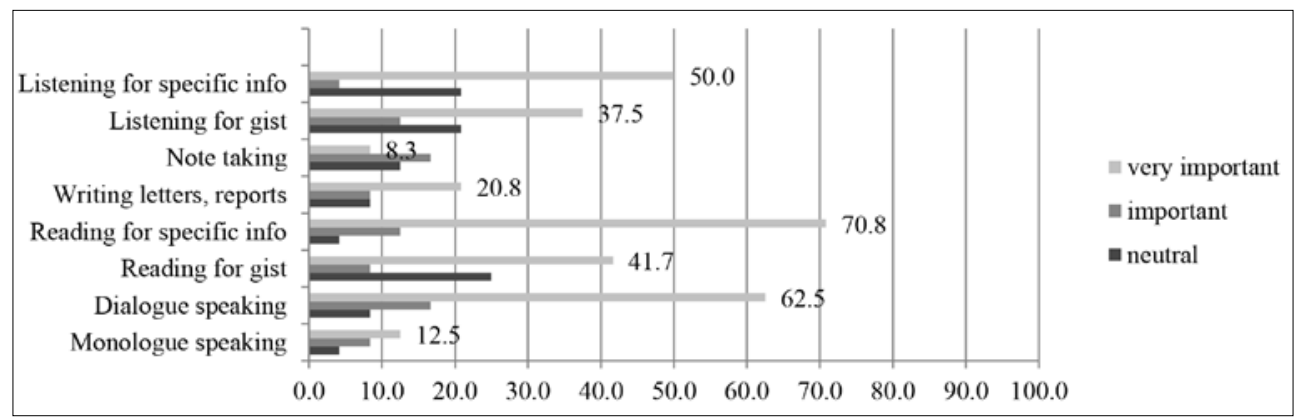

Figure 3. The importance of language skills for work at sea, marine engineering students.

\section{Thematic Syllabus}

The methods of organising SME include content-based instruction (CBI) theme-based courses, where the evaluation is primarily focused on the use of the ME structures, adjunct-model courses with English as an additional course to prepare students for professional study subject delivered in English and sheltered courses, where students are evaluated according to the mastery of the study subject content, and "sheltering" means some English language assistance in acquiring the content of the subject. [5] However, the Model Course regards it as "less suitable for Maritime English teaching“" (p. 182). As in the case of LMA, the theme-based ME courses are provided. There are no study subjects delivered in English for native students, so no preparatory or sheltering courses are offered at LMA.

In order to determine the topics which are the most relevant for the studies, a questionnaire was formed referring to the study topics offered in the Model Course and practically delivered at LMA, empirical observations and analysis of scientific literature.

Students were asked to rank the ME themes according to their importance to the work at sea using the Likert Scale.

The topics were divided into the following areas: general topics (usually delivered in the general ME course for both study programmes) and topics usually delivered for marine engineers and marine navigators specific for each programme. However, no distiction was made between the topics in the questionnaire that could be seen to the respondents. See Figures 4, 5 and 6 for the results of the survey.

As for the general topics (see Figure 4), most of them are regarded as important with Medical Aid being the top priority. It is presently included in the SME programme for marine navigators. Also, the topics that were given the lowest importance were Crew Structure and Reports on Accidents and Emergencies. Thus, the way of presenting these topics could be reconsidered as students may value them less positively due to the content of the course and the context they were presented in. Marine engineers also marked Crew Structure and Duties as a less 
significant topic which may lead to reconsidering the presentation of the topic in a wider context or incorporating in other themes.

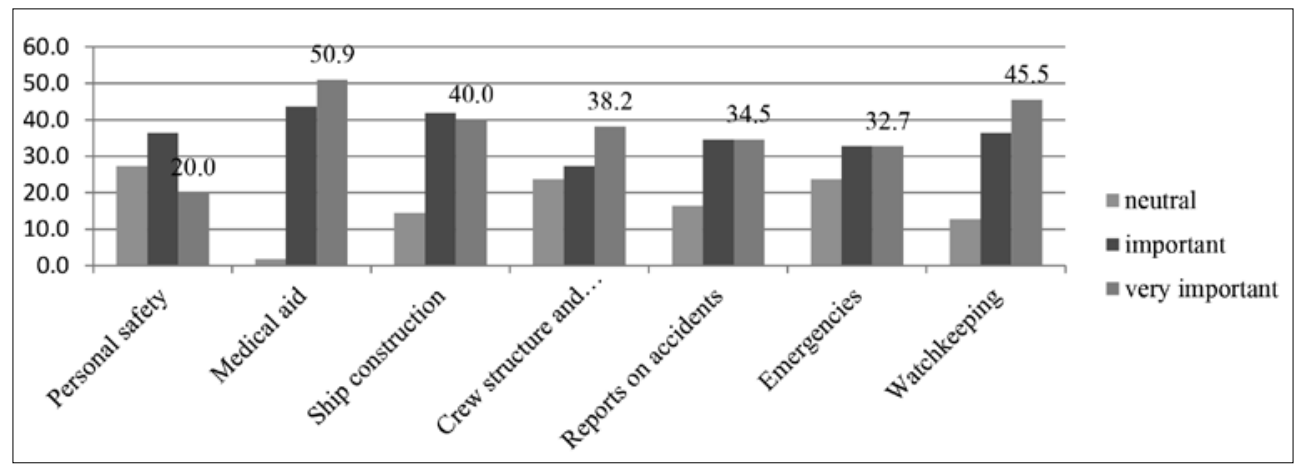

Figure 4. The importance of general topics for marine engineers and marine navigators.

Both marine navigators and marine engineers recognized their topics and marked them as significant. As expected, marine navigation as well as marine engineering students regarded the topics of their study programmes as the most important ones.

Also, marine navigators marked four topics (Life-saving and Fire-fighting Equipment, Hand Tools, Measurement Devices, Permits to Work and Planning and Ordering Spare Parts) from the field of marine engineering as quite important (see Figure 5).

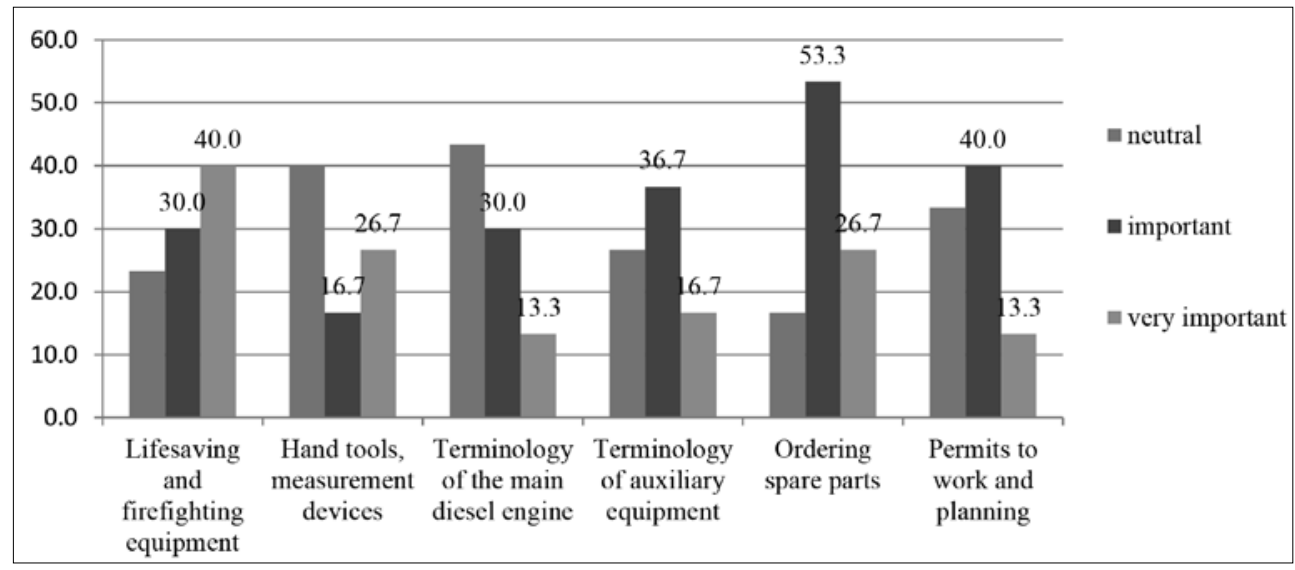

Figure 5. Marine navigation students' choices of topics according to their importance for work at sea.

Marine engineers (see Figure 6) selected some topics from Marine Navigation as important (Shipping Correspondence, Letter Writing, Ship Security and ISPS), but still they were not as important as for marine navigators and should be taken into account when designing the course syllabus. 


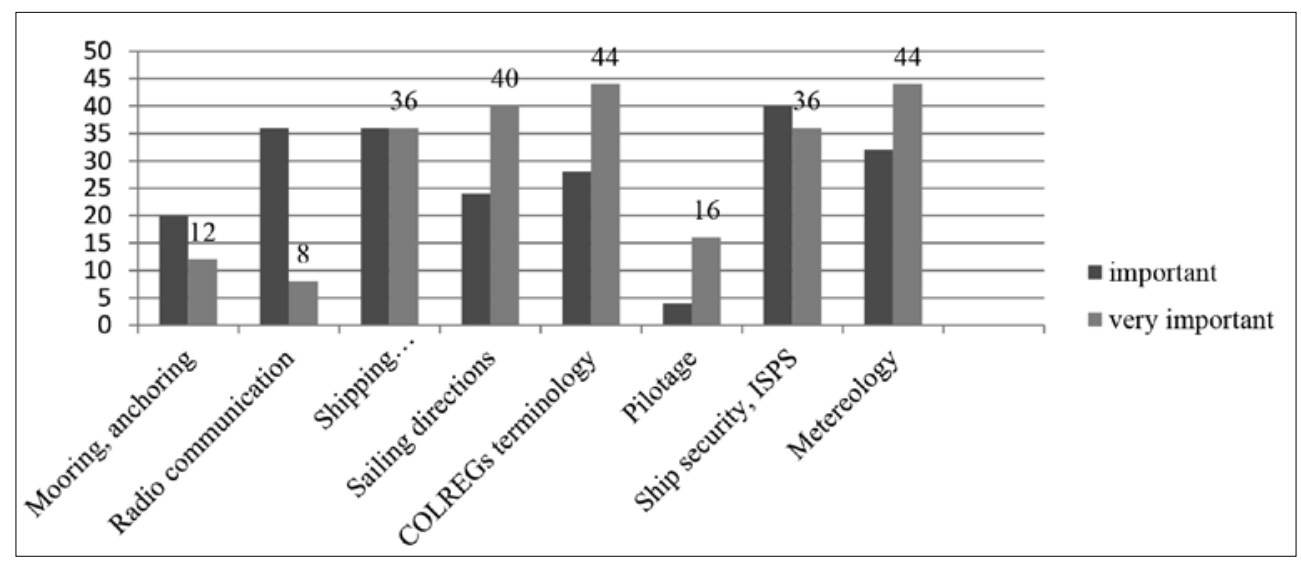

Figure 6. Marine engineering students' choices of topics according to their importance for work at sea.

Thus, the ME areas actually correspond to the needs of the seafaring maritime students as they perceive work at sea with some minor deviations that could be taken into account when designing the ME syllabus.

\section{The Analysis of Open Questions}

The open questions on further development of ME teaching were grouped by meaning and are provided below.

Marine navigators pointed out that it would be useful to practice radio communication more by the means of portable radio sets (4); they required more communication phrases, practical speaking exercises and listening (6); there was a suggestion to deliver professional subjects in English (1).

Marine engineers noted that they required the terms on hand tools and terminology in general (8); more practical listening and speaking exercises (6); reading of manuals and understanding them (1); everything is well, all depends on personal efforts (3). Also, there was a suggestion to improve students' selfintroduction speech skills (1).

Generally, marine navigators are interested in communicative practices, especially in radio communication, while marine engineers' focus is both on professional terminology and communication.

\section{Conclusions}

Teaching ME at the tertiary level is defined by a subject syllabus. The key components of the syllabus set out in formal documents comprise thematic layout of the professional vocabulary areas to be covered within the course with language competencies and language skills to be developed which are set out as the objectives 
of the course.

As a part of ESP, ME has to take into account the students' needs by surveying the needs of the students having seagoing practice for language skills and themes to be covered.

The suggestions for the ME course include the introduction of some topics peculiar for marine engineers or marine navigators to be covered within the programme of another field of study that are different from the recommendations by the Model Course, namely:

- Hand and machine tools taught as a general topic (previously taught to marine engineers);

- Focus on radio communication as well as permits to work for marine navigators;

- The topics of marine security and letter writing for marine engineers together with profession-specific vocabulary in order to enhance the understanding of profession-specific texts (manuals, technical specifications, etc.).

It is important to take into account the students' need for sufficient amount of practical communication exercises for speaking and writing to develop their communicative skills. 


\title{
JŪRINĖS ANGLŲ KALBOS DE்STYMO GAIRIUৃ NUSTATYMAS, REMIANTIS GEBE்JIMŲ IR TEMŲ REIKŠMINGUMO VERTINIMU JŪRINĖS PLAUKIOJIMO PRAKTIKOS KONTEKSTE: ATVEJO STUDIJA
}

\author{
Vilma Pranckevičiūtė
}

\section{Santrauka}

Iki pat šių dienų jūrinè anglų kalba yra tarptautinè kalba, vartojama laivyboje ir jūrinejje industrijoje. Jos mokèjimas yra neatsiejama kiekvieno jūrininko darbo dalis, darantis įtaką tiek laivybos, tiek paties jūrininko saugumui. Savaime aišku, kad jūriné anglų kalba taip pat yra reikšminga jūrininkų profesinio rengimo dalis, kurią reglamentuoja Tarptautinè konvencija dèl jūrininkų rengimo, atestavimo ir budejjimo (angl. STCW). Lietuvos aukštojoje jūreivystès mokykloje jūrinė anglụ kalba taip pat yra dėstoma remiantis Konvencijoje išdėstytais reikalavimais, taip pat remiantis TJO (Tarptautinès jūrų organizacijos) pavyzdiniu kursu (3.17. „Jūrinė anglų kalba"). Tačiau kokių jūrinès anglų kalbos kalbinių gebėjimų labiausia reikia dirbant jūroje? Šiuo straipsniu siekiama atsakyti ị šį klausimą remiantis studentų, turinčių jūrinès plaukiojimo praktikos patirties, apklausos rezultatais, siekiant tobulinti jūrinès anglų kalbos dèstymą.

Straipsnyje trumpai apžvelgiami jūrinès anglų kalbos mokejjimo reikalavimai, keliami jūrininkams tarptautiniuose dokumentuose, bei analizuojami Jūrų laivavedybos ir Laivų energetinių ịrenginių studijų programų ketvirto kurso studentų, jau baigusių jūrinès anglų kalbos kursą ir grịžusių iš jūrinès plaukiojimo praktikos, apklausos rezultatai. Studentų nuomone, kalbinių gebėjimų, tokių kaip klausymas, rašymas, skaitymas, kalbejjimas ir gebejjimas vartoti ịvairių temų jūrinę terminiją reikšmingumas darbui jūroje yra nevienodas. Studentai pabrèžia gebejjimo suprasti techninius tekstus ir klausymo gebejjimų svarbą. Be to, reikšmingas gebejjimas bendrauti (dialoguose), ypač bendraujant radijo ryšiu. Vertinant žodyno mokymosi tematikos reikšmingumą darbui jūroje, tiek Jūrų laivavedybos, tiek Laivų energetinių įrenginių studijų programų studentai ,atpažino“ savo srities temas ir jas įvertino kaip labai reikšmingas. Tačiau jie taip pat ịvertino kitos studijų programos temas kaip reikšmingas nepaisant to, kad jie mokosi tik savo srities jūrinius terminus. Tobulinant jūrinès anglų kalbos dèstymą, reikia atkreipti dėmesị ị bendravimą radijo ryšiu Jūrų laivavedybos studijų programos studentams, o laivų inžinieriams svarbu ugdyti techninių dokumentų skaitymo gebėjimus. Svarbu abiejose studijų programose skirti reikiamą dèmesị praktinèms užduotims, atliekamoms raštu ir žodžiu, kurios ugdo bendravimo gebejjimus. 


\section{References}

1. http://iteslj.org/Articles/Rabbini-Syllabus.html, reviewed on 28-04-2019.

2. https://dictionary.cambridge.org/dictionary/english/, reviewed on 28-04-2019.

3. Common European Framework of Reference for Languages. https://www. coe.int/en/web/common-european-framework-reference-languages/leveldescriptions, reviewed on 28-04-2019.

4. Ilgūnaitienè, R.-V. et al. (2015) Is It Purposeful for Students of Lithuanian Higher Schools to Continue Learning the English Language? Motivation Factors. COACTIVITY: Philology, Educology 23(1), p. 64-72, doi: htttp:dx.doi.org/10.3846/ cpe.2015.265.

5. Model Course 3.17 Maritime English, 2015 Edition. IMO.

6. STCW Code (2010) International Maritime Organisation.

7. Trenkner P., Cole C. (2012) The STCW Manila Amendments and Their Impact on Maritime English, Constanta Maritime University Annals 17. 


\section{AUTORIAUS LYDRAŠTIS}

Autoriaus vardas, pavardè: Vilma Pranckevičiūtè

Mokslo laipsnis ir vardas: edukologijos mokslų magistras

Darbo vieta ir pareigos: Lietuvos aukštoji jūreivystès mokykla

Autoriaus mokslinių interesų sritys: Nuotolinis mokymas (is), jūrinès anglų kalbos mokymas, savarankiškas darbas

Telefonas ir el. pašto adresas: +370 68394 931, v.pranckeviciute@lajm.lt

\section{AUTHOR'S COVER LETTER}

Author's name and surname: Vilma Pranckevičiūtè

Academic degree and name: Master of Science in Education

Workplace and position: Lithuanian Maritime Academy

Author's research interests: distance teaching and learning, teaching Maritime English, independent study

Telephone and e-mail: +370 68394 931; v.pranckeviciute@lajm.lt 